\title{
ICE Relevant Physical-chemical Properties and Air Pollutant Emission of Renewable Transport Fuels from Different Generations - An Overview
}

\author{
György Szabados" Jan Knaup', Ákos Bereczky² \\ 1 Department of Internal Combustion Engines and Propulsion Systems, Audi Hungaria Faculty of Automotive Engineering, \\ Széchenyi István University, H-9026 Győr, Egyetem tér 1., Hungary \\ 2 Department of Energy Engineering, Faculty of Mechanical Egnineering, Budapest University of Technology and Economics, \\ H-1521 Budapest, P.O.B. 91, Műegyetem rkp. 3, Hungary \\ * Corresponding author, e-mail: szabados.gyorgy.gergo@ga.sze.hu
}

Received: 01 September 2019, Accepted: 03 Oktober 2019, Published online: 23 November 2020

\begin{abstract}
The fuel demand in transport sector seems to be raised on a short and also on a long term base in the European Union and worldwide as well. A constantly growing trend is foreseen through 2050 worldwide as for using bio-based energy or fuels. Questions can arise before using these kinds of fuels in connection with the use of clean water or in terms of soil degradation, plant nutrients. It is also questionable whether they can be useful regarding their usage. First-, and second generation liquid as well as third generation gaseous bio-based fuels will be in focus in this article. They will be analyzed from physical-chemical properties and pollutant emission points of view.
\end{abstract}

Keywords

renewable fuels, air pollutant emission, physical-chemical properties

\section{Introduction}

The fuel demand in transport sector seems to be raised in the near and far future regarding the EU and worldwide as well. This situation may lead to an increasing load and pollution from the transport sector (Exxon Mobil, 2018; Economics, 2018; International Energy Agency, 2018; Shell International BV, 2016; Shell, 2018). As for using bio-based energy or fuel, steady upward trend is forecasted until 2050 worldwide (Fischer and Schrattenholzer, 2001). The share of renewable energy in transport energy use will be slightly below $5 \%$ globally (Exxon Mobil, 2018) while that is significantly higher in Europe (Ricardo, 2018) in the long term, while another study suggests that the share of biofuels in transport will be higher (Shell International BV, 2016). There are many initiatives, possibilities to reduce $\mathrm{CO}_{2}$ emission e.g. in Hungary (Zöldy, 2018; Török and Zöldy, 2010).

There are many alternative fuels in the transport sector, which can be a solution instead of the fossil origin conventional one. The biofuels can be found among these opportunities (Zöldy, 2009). The aim of biofuel's usage is primarily the diversification of fuel resources, preservation of fossil stocks and keeping energy security (Hancsók et al., 2006a; Hancsók et al., 2006b; Ajanovic, 2010; MOL Group, 2012; Mantzos, 2010; Exxon Mobil, 2018; Economics, 2018; International Energy Agency, 2018; Shell International BV, 2016; Shell, 2018). Questions can arise before using the fuel in connection with the use of clean water or in terms of soil degradation, plant nutrients (Reijnders, 2019). Requirements regarding utilization rate of the renewable energy are set out in (European Parliament and Council, 2009). This utilization rate differs from county to country. For example in Poland this value is not so high approximately $12 \%$, while the share of renewable energy compared to the total energy consumption reaches the $42 \%$ making it a world leader from this point of view (Maczyńska et al., 2019), but much of it comes from wood burning heating. It is also questionable whether they can be useful regarding their usage. First to mention their effect on emission of an internal combustion engine because it is a mixed situation. It means that regarding certain components 
they have advantages, so these components like $\mathrm{CO}, \mathrm{HC}$ decrease using biofuel and other emission-components for example particulate mass increases (Gruden, 2008; Whittaker et al., 2011; Vidal Quadras, 2010).

Biofuels can be classified into different generations (Alalwan et al., 2019; Saladini et al., 2016; Dahman et al., 2019). The spread of biofuels of first generation is currently in process. Biodiesel and bioethanol can be classified for the first generation. Usually they are blended in a low level rate to fossil fuels (MOL Group, 2012), but there are some examples in different European cities where they are used at a higher level blending rate or pure themselves for city buses (CIVITAS, 2011). Fuels from bio-origin are expensive, bio components are the most expensive ones among additives and components which are added to fossil fuels to make it fit for using in internal combustion engine (Tóth, 2011; Zöldy et al., 2011). Physical-chemical properties, composition of these first generation fuels are regulated in one European Standard for biodiesel (European Standard EN 14214, 2008), and in another one for bioethanol (European Standard EN 15376, 2008).

Fuels from the second generation have other basic materials that are produced by a different way compared to first generation's fuel. The raw materials are also different such as wood, grasses waste product of animals, newspapers, agricultural waste crops in most of cases. Enzymes and microorganisms are designed using synthetic biology which should substantially increase the energy yield of these raw materials (Bhatia et al., 2017; Ahmed-Sarkar, 2018; Then et al., 2010). A serious disadvantage of these fuels can be their water solubility which is a problem regarding transportation, storage and combustion as well (Dechambre et al., 2017). Many ICE relevant properties of these fuels are similar to those of fossil derived fuels and because of their composition they are supposed to be more environmentally friendly ones. There are also fuels with fossil base among second generation's fuels. Learning, designing and refining of technologies is in process (Vidal Quadras, 2010; Paraffinic fuels for Europe, 2017; Larson, 2008; Rantanen, 2005).

The use of hydrogen and methane produced on a bio-basis is on a level of a demonstration project. They can be used in internal combustion engine. The technology that is used to produce these gaseous fuels does not play role as for their usage in engines. Beside the disadvantages of their production technology they are highly appreciated from their very low level air pollution of view (Eichlseder and Klell, 2010).
Generally, renewable fuels from 3. Generations are produced from plants or other crops that are unrelated to food production. There is a literature, which considers microbial lipids as 3rd generation fuel (Leong et al., 2018). According to some other literature, 3rd generation fuels on micro-algae basis are increasingly distributed (Alaswad et al., 2015; Dragone et al., 2010; Brennan and Owende, 2010).

Genetically modified algal biofuel can be classified as 4th generation biofuels. This kind of fuel has advantages and disadvantages as well. Non-mature manufacturing technology coupled with low number of results from using them e.g. in engines. According to Abdullah et al. (2019) they are a promising alternative for fossil fuel with high energy content, low emission, and non-polluting nature. However, production of the algal biofuel is not economically viable due to the low yield and high production costs at this time.

First-, and second generation liquid as well as third generation gaseous bio-based fuels will be in focus in this article. They will be analyzed from physical-chemical properties and pollutant emission points of view.

\section{About the transportation biofuels in general}

\subsection{Grounds for using bio-derived fuels, technologies for their processing and production}

The possibility for spreading of fuels and lubricants with bio origin is a question of balance with appropriate proportion among agricultural products for food and feed and agricultural products for industrial use. Another criterion is that the cost of purchasing and the quality of biofuels compared to fossil fuels should be more or less the same. In addition, those kind of biofuels come onto the market that do not require any modification of modern vehicles today or only minimal modification needed. Modernization of existing production technologies of fuels and lubricants can be reached significant saving in resources and stock furthermore in emission of air pollutants (Hancsók et al., 2006b; Barabás et al., 2015; Zöldy and Török, 2015).

Most important reasons of using transportation fuels from bio sources:

- Reducing $\mathrm{CO}_{2}$ emissions responsible for global warming, which biofuel itself alone is a realistic option for a short and medium term base;

- Reducing the dependence of transport from fossil (primarily oil-based) sources;

- Creating (preserving) a job in agriculture, and utilizing occasional overproduction as well as abandoned land parts. 
Renewable, biomass origin fuels are counted fuels which have a source of vegetable or possible of and their stock does not decrease because they are renewed, reproduced. The more important bio-derived transportation fuels are as follows: bio-alcohols, vegetable oils, bioethers, biogas. Among these have to be mentioned bioethanol and biodiesel which are the most common globally and in our land as well. They are blended to gasoline and diesel respectively with a certain level on volumetric base (Hancsók et al., 2006b).

\section{Biofuels of first generation (alcohol, FAME)}

Biomass derived gasoline components of Otto-engines are called nowadays which are produced entirely or partially from biomass (e.g. from wood, corn, straw or from animal origin materials, etc.) in order to reduce the dependency from fossil origin fuels and to reduce the emission of pollutants with global warming effect. Fuels produced exclusively from biomass are bio-methanol, bioethanol and synthetic gasoline from synthesis gas with FischerTropsch-synthesis. Fuels produced partially from bio origin materials are the methyl-ethers (MTBE, TAME, etc) and ethyl-ethers (ETBE, TAEE, etc.). As for methyl-ethers and ethyl-ethers the proportion of bio origin materials is ca. 35-45\%. Producing bioethanol can be a process e.g. fermentation from sugar, fermentation of hydrolyzed amylum or fermentation of specially prepared and hydrolyzed cellulose (Hancsók et al., 2006b).

For propelling Diesel-engines - beside the conventional fuels - biomass derived fuels are also available. These include biodiesels (Fatty-Acid-Methyl-Esters from different stock), other oxygen containing compounds (e.g. ethanol, dimethyl-ether), furthermore the new generation of biodiesel like mixture of n- and i-paraffines produced from vegetable's triglycerides, synthetic diesel (mixture of synthetic n- and i-paraffines, Fischer-Tropsch-diesel) and bio-paraffines manufactured from carbohydrate. Among these fuels there are some which can be used in a pure form in Diesel-engine e.g. biodiesel, dimethyl-ether and there are some which is appropriate only as a blending component for example ethanol without any modification of the engine. Biodiesels are produced in a way, where the vegetable's tri-glycerides are modified into a form with less molecule scale and the average molecule mass is also less. It is a goal as well that the product would be low unsaturated. The widely used technologies are as follows:

- catalytic esterification of triglycerides with alcohols;

- hydrogenation of triglycerides with different depths (Hancsók et al., 2006a).

\subsection{Air pollution effect of biofuels from the first generation}

\subsubsection{The bioethanol}

The effects of blending bioethanol in gasoline on vehicle emissions have been investigated in numerous on engine and in vehicle fleet as well. Based on these evaluations, it can be concluded that the evolution of the emission of pollutants (carbon-monoxide, hydro-carbons, nitrogen-oxides) is mainly influenced by the engine design and combustion process. It cannot be clearly stated that blending ethanol always results in a reduction in $\mathrm{CO}$ and $\mathrm{HC}$ emissions and an increase in nitrogen-oxide emissions.

There is a significant difference regarding emission between e.g. older cars equipped with carburetors and advanced vehicles equipped with electronically controlled injection system. Engines with carburetor do not adapt to the lower stoichiometric air/gasoline ratio of the ethanol-gasoline blend, which results in the mixture becoming poorer, which means that more oxygen is sucked into the combustion chamber compared to the operation with pure gasoline. It slightly improves the combustion of hydrocarbons, but mainly promotes the oxidation of carbon monoxide. Of course, it does not matter whether the vehicle is equipped with catalytic converter or not. The test procedure also significantly determines the emissions of an engine or vehicle. Therefore, it is only appropriate to talk about trends in connection with emissions emitted by an engine or vehicle. In general, engines with advanced electronic control vehicles have 5-30\% less hydrocarbon and carbon monoxide emissions when blending 10-20 V/V \% ethanol in gasoline. However, nitrogen-oxide emissions are generally $10-40 \%$ higher may be because of better combustion resulting in higher flame temperatures, which favors the formation of nitrogen oxides. It is important to note the emission of acetaldehyde, which is extremely harmful to human health, is clearly increased in any engine type using ethanol and that ethanol is present in the exhaust gas in measurable quantities. One of the important goals of the use of bio-based components is to reduce greenhouse gas emissions $\left(\mathrm{CO}_{2}, \mathrm{~N}_{2} \mathrm{O}\right.$, etc. $)$ throughout the whole life cycle of the fuel. Greenhouse gas emissions during of a fuel's life cycle depend on many factors, for example, on the type of basic material, on the type of production technology, the ethanol content of gasoline as well as on the type of vehicle, etc. According to recent reports using bioethanol from maize can reduce greenhouse gas emissions by 18-29\% compared to conventional motor gasoline with the same energy content when used in the form of E10 (Hancsók et al., 2006b). 


\subsubsection{The biodiesel}

RME, which is the most widely produced and used in the European Union, can reduce GHG emissions by up to $50 \%$. Blending biodiesel into diesel can have a detrimental effect on NOx emissions and can have a positive impact on emission of particulates, $\mathrm{HC}$ and $\mathrm{CO}$. For newer vehicles, particle emissions from the $\mathrm{B} 100$ can be reduced by almost $75 \%$, while NOx emissions can increase by up to $30 \%$ compared to biodiesel-free diesel (Hancsók et al., 2006a).

\section{Biofuels of second generation (synthetic fuels) 4.1 Introduction and ICE relevant properties}

Second-generation synthetic biofuels are pure, high-quality fuels made from a variety of raw materials. One possible solution is to produce it from lignocellulose-based biomass, which allows the use of lower-cost inedible raw materials, thus limiting direct food fuel competition. Second generation fuels can be classified in terms of the process of converting biomass to fuel. Accordingly, there is a biochemical and thermochemical conversion process. Ethanol or butanol of second generation are produced by a biochemical process. Second generation's biofuels produced by thermochemical processes are less well known because they have no first-generation "equivalent" fuel. There are many second-generation biofuels produced by thermochemical process that can be manufactured from ordinary fossil feedstock, have similar processes to those used to produce biofuels. Such biofuels include methanol, Fischer-Tropsch liquid, and dimethyl ether. Blended alcohols can also be produced from fossil fuels, but this process is not yet widespread due to the immaturity of the technical solution. Unrefined fuels such as pyrolysis oils are produced by thermochemical processes in such a way that they do not require any further treatment and refining before use in engines. Fig. 1 shows the potential for the production of second generation's biofuels (Larson, 2008).

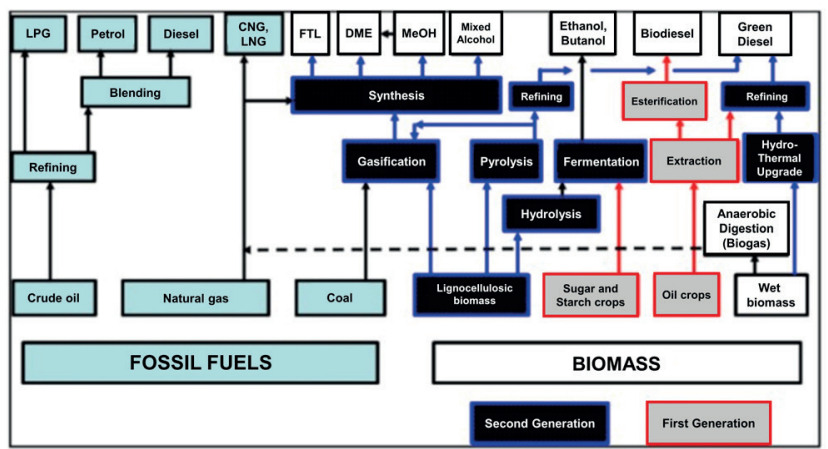

Fig. 1 Possibilities for the production of second generation fuels (Larson, 2008)
Regardless of the raw material used, the following can be said for all synthetic biofuels:

- sulfur-free, low-aromatic, odourless, colourless liquid fuel;

- it allows for a significant reduction in regulated and unregulated exhaust components from vehicles $\left(\mathrm{NO}_{\mathrm{x}}, \mathrm{SO}_{\mathrm{x}}, \mathrm{PM}, \mathrm{VOC}, \mathrm{CO}, \mathrm{HC}, \mathrm{CO}_{2}\right)$;

- contributes to the replacement of fossil crude oil, improves diversification opportunities and contributes to security of energy supply;

- can be used in existing fuel infrastructures;

- can be used in existing engines;

- enables the development of a new generation of internal combustion engine technologies to improve engine efficiency and reduce pollutant emissions;

- easily degradable and non-toxic to organisms (Paraffinic fuels for Europe, 2017).

Advantageous properties of synthetic fuels are shown in Fig. 2. Synthetic biofuels also have many advantages compared to fossil fuels and first generation biofuels. Table 1 summarizes the data for the different fuels from four relevant technical point of view.

\subsubsection{Parameters of Nesteoil NExBTL biofuel}

The NExBTL biodiesel is a mixture of normal and iso-paraffines. Its features are comparable to the best premium fossil diesel fuel available today. When added to fossil, the NExBTL component improves the diesel's quality. The NExBTL biodiesel is compatible with existing vehicle fleet and fuel delivery system and blending into diesel is technically easy. The chemical structure of NExBTL and most GTL fuels is different from that of the currently well-known biodiesel (FAME). The long-chain methyl ester of FAME fatty acids, which contains oxygen in the ester group, while NExBTL hydrocarbon-based biodiesel does not contain oxygen.

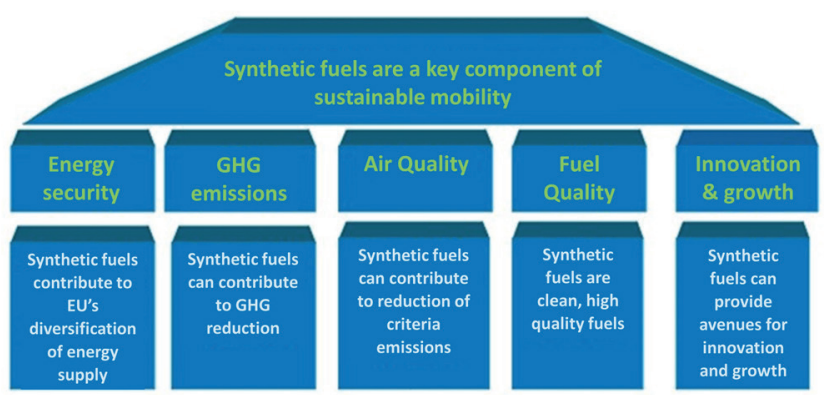

Fig. 2 Advantages of second generation synthetic fuels (Vidal Quadras, 2010) 
Table 1 Comparison of some ICE relevant properties of possible Dieselengine fuel (Vidal Quadras, 2010)

\begin{tabular}{lcccc}
\hline & $\begin{array}{c}\text { Diesel } \\
(\text { EN 590) }\end{array}$ & $\begin{array}{c}\text { FAME (EN } \\
14214, \text { max. } \\
7 \mathrm{~V} / \mathrm{V} \% \text { in } \\
\text { EN 590) }\end{array}$ & $\begin{array}{c}\text { Sysnthetic } \\
\text { fuels (SF) } \\
\text { (CEN CAW } \\
15940)\end{array}$ & $\begin{array}{c}\text { SF as } \\
\text { alternative } \\
\text { to diesel }\end{array}$ \\
\hline $\begin{array}{l}\text { Sulfur } \\
\text { content }\end{array}$ & $\begin{array}{c}<10 \mathrm{~m} / \mathrm{m} \\
\mathrm{ppm}\end{array}$ & $\begin{array}{c}<10 \mathrm{~m} / \mathrm{m} \\
\mathrm{ppm}\end{array}$ & $\begin{array}{c}<1 \mathrm{~m} / \mathrm{m} \\
\mathrm{ppm}\end{array}$ & ++ \\
$\begin{array}{l}\text { Aromatics } \\
<11 \mathrm{~m} / \mathrm{m} \%\end{array}$ & n.a. & $<0.1 \mathrm{~m} / \mathrm{m} \%$ & ++ \\
$\begin{array}{l}\text { Cetane } \\
\text { number }\end{array}$ & $>51$ & $>51$ & $>70$ & ++ \\
$\begin{array}{l}\text { Oxidation } \\
\text { stability }\end{array}$ & ++ & - & ++ & ++ \\
\hline
\end{tabular}

The NExBTL fuel does not contain sulphur, oxygen, nitrogen and aromatics. The cetane number is very high approximately 90. Cold temperatures (turbidity point) can be set by the factory to be between $-5^{\circ} \mathrm{C}$ and $-30{ }^{\circ} \mathrm{C}$ in order to meet different environmental conditions. The lubricity of NExBTL biodiesel can be easily improved with the amount of additives used today for conventional sulfur-free diesel oil. The NExBTL complies with both the related European Standard (European Committee For Standardization, 2005) and the Specification 4 of the WWFC. Table 2 shows the NExBTL fuel characteristics compared to other fuels. Based on Table 1, the following can be stated regarding the fuel's ICE relevant properties: its lower density compared to conventional diesel gives better sprayability and easier transport. The significantly higher cetane number improves the inflammatory property, which can become a disadvantage after a certain point. The cloud point is significantly lower than that of other fuels. Its heating value is approximately the same as conventional diesel, which means that the fuel-powered engine has similar power and fuel consumption. It does not contain PAHs, oxygen and sulphur, which can significantly reduce pollutant emissions like soot and particle (Rantanen et al., 2005).

\subsection{Introduction of properties regarding pollutant emission}

The use of synthetic fuels in internal combustion engines reduces pollutant emissions, contributing to better air quality, especially in urban environments. Fig. 3 shows the emissions of different pollutants based on data obtained from a comparison of fossil diesel and synthetic motor fuels. Road tests with synthetic fuels in several European countries show, that these propellants significantly improve local air quality through reduced emissions of air pollutants
Table 2 Properties of conventional, first and second generation Dieselengine fuels (Rantanen et al., 2005; Rimkus et al., 2015; European Committee For Standardization, 2005)

\begin{tabular}{lcccc}
\hline FUEL PROPERTIES & $\begin{array}{c}\text { NExBTL } \\
\text { biodiesel }\end{array}$ & $\begin{array}{c}\text { GTL } \\
\text { diesel }\end{array}$ & $\begin{array}{c}\text { FAME } \\
\text { (RME) }\end{array}$ & $\begin{array}{c}\text { EN 590 } \\
/ 2005\end{array}$ \\
\hline $\begin{array}{l}\text { Density at } 15^{\circ} \mathrm{C} \\
{\left[\mathrm{kg} / \mathrm{m}^{3}\right]}\end{array}$ & $775 \div 785$ & $770 \div 785$ & $860 \div 900$ & $820 \div 845$ \\
Viscosity at $40^{\circ} \mathrm{C}$ & $2.9 \div 3.5$ & $3.2 \div 4.5$ & $3.5 \div 5$ & $2 \div 4.5$ \\
{$\left[\mathrm{~mm}^{2} / \mathrm{s}\right]$} & & & & \\
Cetane number & $84 \div 99$ & $73 \div 81$ & $>51$ & $>51$ \\
$\begin{array}{l}\text { Distillation } 10 \text { vol\% } \\
{\left[{ }^{\circ} \mathrm{C}\right]}\end{array}$ & $260 \div 270$ & $\sim 260$ & $\sim 340$ & $\sim 200$ \\
$\begin{array}{l}\text { Distillation } 90 \text { vol\% } \\
{\left[{ }^{\circ} \mathrm{C}\right]}\end{array}$ & $295 \div 300$ & $325 \div 330$ & $\sim 355$ & $\sim 350$ \\
Cloud point [ $\left.{ }^{\circ} \mathrm{C}\right]$ & $-5 \div-30$ & $0 \div-25$ & $\sim-5$ & $\sim-5$ \\
Lower heating value & $\sim 44$ & $\sim 43$ & $\sim 38$ & $\sim 43$ \\
{$[\mathrm{MJ} / \mathrm{kg}]$} & & & & \\
Lower heating value & $\sim 34$ & $\sim 34$ & $\sim 34$ & $\sim 36$ \\
{$[\mathrm{MJ} /$ litres] } & & 0 & 0 & $<11$ \\
Polyaromatics [wt $\%]$ & 0 & 0 & $\sim 11$ & 0 \\
Oxygen [wt $\%]$ & 0 & 0 & $<10$ & $<10$ \\
Sulfur [mg $/ \mathrm{kg}]$ & $\sim 0$ & $<10$ & $<$
\end{tabular}

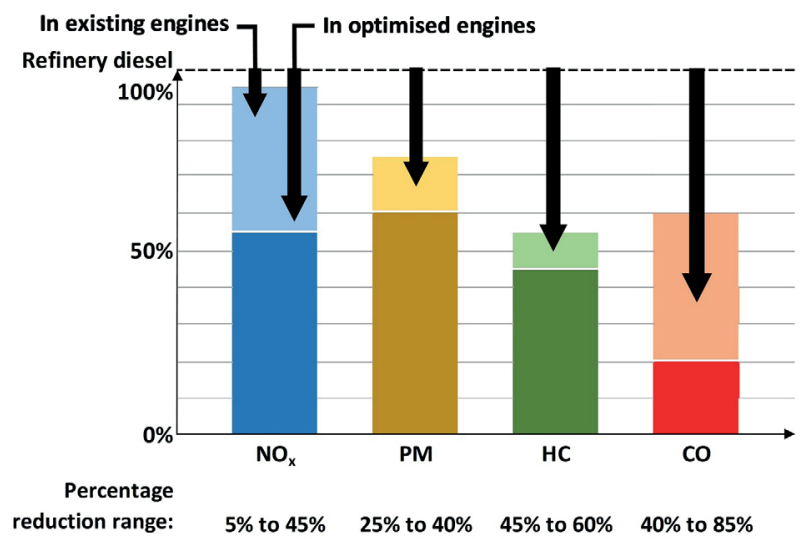

Fig. 3 Reduction of emissions from the most important components through the use of second generation fuel (Vidal Quadras, 2010)

(particulate matter, nitrogen-oxides, carbon-monoxide and hydrocarbons). Using synthetic fuel, PM reduction can be achieved as shown in Fig. 4. If the engine is optimized $\mathrm{NO}_{\mathrm{x}}$ reduction can be achieved.

The test, the results of which are shown in Fig. 3, has been conducted with a EURO 4 Toyota car without exhaust after-treatment system. The comparison test series was based on the type-approval test procedure with different types of biofuels. Results show the two most typical exhaust gas components for the Diesel-engine, $\mathrm{PM}$ and $\mathrm{NO}_{\mathrm{x}}$ (Gray Field: Diesel Fuel, Normal Engine; Light Blue Field: GTL Fuel Normal Engine; Dark Blue Field: GTL Fuel, Optimized Engine) (Vidal Quadras, 2010). 


\subsection{Greenhouse gas emissions}

The environmental characteristics of conventional and synthetic fuel technologies were established by Well-ToWheel based life cycle analysis. Studies show that GTL's total process' greenhouse gas emissions are comparable to those of a conventional refinery system. HVO shows a $40-80 \%$ reduction over conventional fuel. Regarding the refinery system, BTL represents 80-90\% pure improvement. Combined engine development and synthetic fuel technologies will lead to significant $\mathrm{CO}_{2}$ reductions (Vidal Quadras, 2010). These statements can be seen in Fig. 5.

\section{Third generation biofuels (hydrogen, methane)}

\subsection{Introduction of ICE relevant properties}

\subsubsection{Hydrogen}

The hydrogen-internal combustion engine process is based on the process of conventional internal combustion engines (most often by the Otto process), however, some conversation has to be carried out in the mixture formation in order that the system be able to operate with hydrogen itself or for dual-mode operation. Thus, they can operate with hydrogen or with hydrogen-containing gases (hydrogen-natural gas). Although most research work focusing

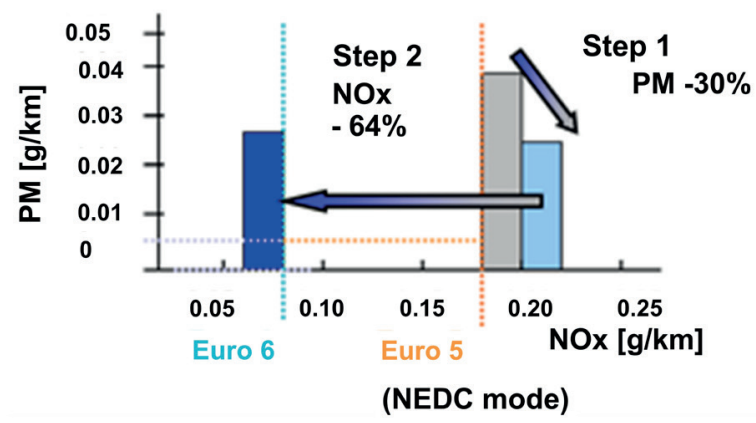

Fig. 4 Reduction in particle emissions through the use of second generation fuel (Vidal Quadras, 2010)

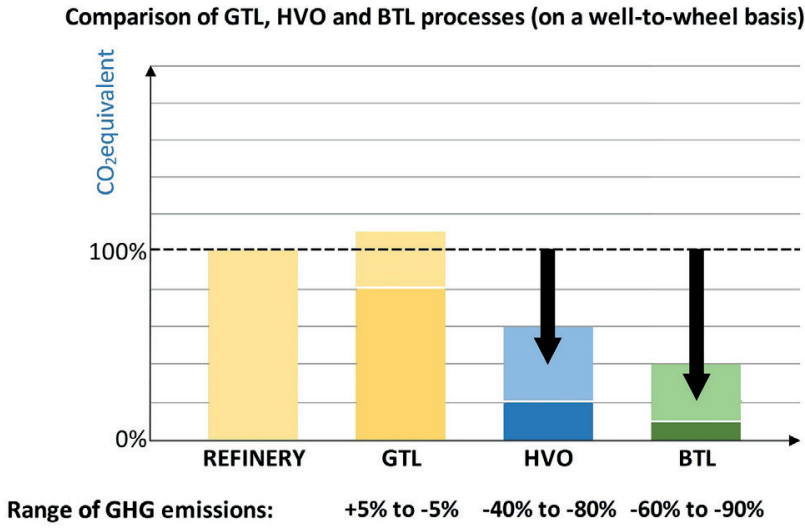

Fig. 5 Reduction of GHG emissions by using second generation fuels (Vidal Quadras, 2010) on hydrogen-based fuel cell power generation concept but hydrogen-powered internal combustion engines are also seen as a competitive, good alternative. The use of hydrogen engines makes it possible to use current production lines in the automotive industry as well as applications common in the vehicles. The properties of hydrogen are fundamentally different from those of fuels used in internal combustion engines for the time being. The gas state at ambient temperature is the most striking, but by no means the biggest difference against gasoline and diesel (Eichlseder and Klell, 2010). Table 3 compares the properties of hydrogen with respect to its use in an internal combustion engine to conventional fuels. Unlike the high energy content of hydrogen in mass $\left(H_{u}=120 \mathrm{MJ} / \mathrm{kg}\right)$, the calorific value per unit volume of hydrogen-air mixture $\left(\mathrm{MJ} / \mathrm{m}^{3}\right)$ is very low. Under real operating conditions, the volume-to-volume calorific value of the hydrogen-air mixture is significantly lower than that of a conventional fuel blend. The wide ignition limits of hydrogen allow quality control over the entire operating range of the engine. One significant difference from conventional fuels is that the hydrogen-air homogeneous mixture can theoretically be burned up to $\lambda=10$ using conventional ignition technology. However, the required ignition energy, as with conventional fuels, increases with increasing air to fuel ratio. The ignition energy required to ignite a stoichiometric hydrogen-air mixture is less than one-tenth the energy required to ignite a gasoline-air mixture. In contrast, the hydrogen self-ignition temperature is significantly higher than that of conventional fuels. This can be an advantage in Otto-process applications for knock formation, but also requires higher compression ratios and other measures to increase the temperature when used in Diesel-engines. High laminar flame velocity enables hydrogen to produce extremely short and very efficient combustion times. Even in the poor mixture range, the laminar combustion rate is significantly higher than what can be achieved with conventional fuels. However, due to rapid combustion and high pressure rise (high $\Delta p / \Delta t$ ), the crankshaft unit is heavily loaded and excited. Overall, due to the above-described properties of hydrogen, it can be used as fuel for internal combustion engines. As for the ignition entry method we can distinguish the two different method so the external ignition and compression ignition in the case of hydrogen engines. Due to the relatively high auto-ignition temperature of hydrogen compared to diesel fuel, which is approximately $585^{\circ} \mathrm{C}$, stable self-ignition operation can only be achieved with high compression ratio and partly 
Table 3 The most important ICE relevant properties of hydrogen and conventional fuel (Eichlseder and Klell, 2010)

\begin{tabular}{|c|c|c|c|c|c|}
\hline ICE relevant property & & Measurement unit & Gasoline & Diesel & Hydrogen \\
\hline Density (liquid) ${ }^{1}$ & & $\mathrm{~kg} / \mathrm{m}^{3}$ & $750 \div 770$ & $820 \div 845$ & 70.8 \\
\hline at temperature & & ${ }^{\circ} \mathrm{C}$ & 15 & 15 & -253 \\
\hline Density (gas) $)^{1,2}$ & & $\mathrm{~kg} / \mathrm{m}^{3}$ & - & - & 0.09 \\
\hline Molmass & & $\mathrm{kg} / \mathrm{kmol}$ & $\sim 98$ & $\sim 190$ & 2.016 \\
\hline Boiling point or - range ${ }^{1}$ & & ${ }^{\circ} \mathrm{C}$ & $30 \div 190$ & $210 \div 355$ & 252.8 \\
\hline Stoichiometric & & $\mathrm{kg}_{\text {air }} / \mathrm{kg}_{\text {fuel }}$ & 14 & 14.7 & 34.2 \\
\hline air demand & & $\mathrm{Vol} \%$ & - & - & 29.5 \\
\hline Lower heating value & & $\mathrm{MJ} / \mathrm{kg}$ & 41.4 & 42.9 & 150 \\
\hline \multirow{2}{*}{ Energydensity } & liquid $^{1}$ & \multirow{2}{*}{$\mathrm{MJ} / \mathrm{dm}^{3}$} & 31.7 & 35.8 & 8.5 \\
\hline & gas & & - & - & $3.06)$ \\
\hline $\begin{array}{l}\text { Heating value of mixture }{ }^{1,2,4} \\
\text { mixture intake }\end{array}$ & & $\mathrm{MJ} / \mathrm{dm}^{3}$ & 3.76 & - & 3.19 \\
\hline $\begin{array}{l}\text { Heating value of mixture }{ }^{1,2,4} \\
\text { air intake }\end{array}$ & & $\mathrm{MJ} / \mathrm{dm}^{3}$ & 3.83 & 3.77 & 4.52 \\
\hline \multirow[t]{2}{*}{ Ignition limits ${ }^{1,3,5}$} & & Volume $\%$ & $1 \div 7.6$ & $0.6 \div 5.5$ & $4 \div 76$ \\
\hline & & $\lambda$-range & $1.4 \div 0.4$ & $1.35 \div 0.48$ & $10 \div 0.13$ \\
\hline Auto-ignition temperature ${ }^{1,5}$ & & ${ }^{\circ} \mathrm{C}$ & $230 \div 450$ & 250 & 585 \\
\hline Minimal ignition energy $y^{4,5}$ & & $\mathrm{~mJ}$ & 0.24 & 0.24 & 0.17 \\
\hline Laminar flame velocity ${ }^{1,3,4,5}$ & & $\mathrm{~cm} / \mathrm{s}$ & $\sim 40$ & $\sim 40$ & $\sim 230$ \\
\hline $\mathrm{ROZ}$ & & - & 100 & - & - \\
\hline $\mathrm{MZ}$ & & - & 88 & - & 0 \\
\hline $\mathrm{CZ}$ & & - & - & $52 \div 54$ & - \\
\hline C content & & $\mathrm{W} \%$ & 85.6 & 86.1 & 0 \\
\hline H content & & $\mathrm{w} \%$ & 12.2 & 13.9 & 100 \\
\hline O content & & $\mathrm{w} \%$ & 2.2 & 0 & 0 \\
\hline
\end{tabular}

1) at pressure 1.013 bar; 2) at temperature $0{ }^{\circ} \mathrm{C} ; 3$ ) at $25^{\circ} \mathrm{C}$; 4) at $\lambda=1$; 5) in air; 6) at pressure 250 bar and temperature $280 \mathrm{~K}$

with additional air preheating. The current field of application of $\mathrm{H}_{2}$-fueled internal combustion engines to drive a passenger car is no longer confined to the Otto-engine concept there was no lack of research and concepts in the past for hydrogen-powered passenger car diesel engines and two-stroke Otto-engines (Eichlseder and Klell, 2010).

\subsubsection{Methane}

The critical temperature for methane compared to other hydrocarbons used as fuel is very low at $-82.5^{\circ} \mathrm{C}$, therefore, it cannot be pressurized at ambient temperature in a liquid state. Vehicle fuel storage is thus practically accomplished by high pressure compression (200-250 bar). Without high pressure compression, the calorific value of methane per unit volume is only about $1 / 1000^{\text {th }}$ of the diesel, $0.036 \mathrm{MJ} /$ $\mathrm{dm}^{3}$ compared to $34.7 \mathrm{MJ} / \mathrm{dm}^{3}$ for diesel. Thus, using the usual 200 bar operating pressure, the density of methane at ambient pressure and temperature is $129.5 \mathrm{~kg} / \mathrm{m}^{3}$ instead of $0.7 \mathrm{~kg} / \mathrm{m}^{3}$. A 100 litres high pressure cylinder can hold about $13 \mathrm{~kg}$ of natural gas with an energy content of approximately equivalent to 19-20 litres of diesel. By the way, this is a very important issue for the car operator (disadvantage), namely, the high storage volume requirement (about five times that of diesel) and the high weight (weight) of high-strength tanks due to high storage pressure (Eichlseder and Klell, 2010). The most important characteristics of methane are given in Table 4.

At ambient pressure, natural gas can be kept in a liquid state at $161.5^{\circ} \mathrm{C}$. LNG is internationally designated by the English abbreviation. The use of LNG as a fuel requires special containers with a very good thermal isolation, which is also called cryogenic container, which is very expensive. A further disadvantage is the constant evaporation loss due to heat absorption due to imperfect heat isolation. The use of LNG as a fuel for heavy duty vehicles is mainly considered there, where the liquefied natural gas arrives at the place of use in liquid form, thus, no additional liquefaction costs are incurred. Methane has more 
Table 4 The most important ICE relevant properties of methane and conventional fuels (Eichlseder and Klell, 2010)

\begin{tabular}{|c|c|c|c|c|c|}
\hline ICE relevant property & & Measurement unit & Gasoline & Diesel & Methane \\
\hline Density (liquid) ${ }^{1}$ & & $\mathrm{~kg} / \mathrm{m}^{3}$ & $750 \div 770$ & $820 \div 845$ & 423 \\
\hline at temperature & & ${ }^{\circ} \mathrm{C}$ & 15 & 15 & -162 \\
\hline Density (gas) ${ }^{1,2}$ & & $\mathrm{~kg} / \mathrm{m}^{3}$ & - & - & 0.716 \\
\hline Molmass & & $\mathrm{kg} / \mathrm{kmol}$ & $\sim 98$ & $\sim 190$ & 16.043 \\
\hline Boiling point or - range $\mathrm{e}^{1}$ & & ${ }^{\circ} \mathrm{C}$ & $30 \div 190$ & $210 \div 355$ & -161.5 \\
\hline Stoichiometric & & $\mathrm{kg}_{\text {air }} / \mathrm{kg}_{\text {fuel }}$ & 14 & 14.7 & 17.2 \\
\hline air demand & & Vol\% & - & - & 9.5 \\
\hline Lower heating value & & $\mathrm{MJ} / \mathrm{kg}$ & 41.4 & 42.9 & 50 \\
\hline \multirow{2}{*}{ Energydensity } & liquid $^{1}$ & \multirow{2}{*}{$\mathrm{MJ} / \mathrm{dm}^{3}$} & 31.7 & 35.8 & 21 \\
\hline & gas & & - & - & 12.66) \\
\hline $\begin{array}{l}\text { Heating value of mixture }{ }^{1,2,4} \\
\text { mixture intake }\end{array}$ & & $\mathrm{MJ} / \mathrm{dm}^{3}$ & 3.76 & - & 3.4 \\
\hline $\begin{array}{l}\text { Heating value of mixture }{ }^{1,2,4} \\
\text { air intake }\end{array}$ & & $\mathrm{MJ} / \mathrm{dm}^{3}$ & 3.83 & 3.77 & 3.76 \\
\hline \multirow[t]{2}{*}{ Ignition limits ${ }^{1,3,5}$} & & Volume $\%$ & $1 \div 7.6$ & $0.6 \div 5.5$ & $4.4 \div 15$ \\
\hline & & $\lambda$-range & $1.4 \div 0.4$ & $1.35 \div 0.48$ & $2.28 \div 0.6$ \\
\hline Auto-ignition temperature ${ }^{1,5}$ & & ${ }^{\circ} \mathrm{C}$ & $230 \div 450$ & 250 & 595 \\
\hline Minimal ignition energy $y^{4,5}$ & & $\mathrm{~mJ}$ & 0.24 & 0.24 & 0.29 \\
\hline Laminar flame velocity ${ }^{1,3,4,5}$ & & $\mathrm{~cm} / \mathrm{s}$ & $\sim 40$ & $\sim 40$ & $\sim 42$ \\
\hline $\mathrm{ROZ}$ & & - & 100 & - & 130 \\
\hline $\mathrm{MZ}$ & & - & 88 & - & 100 \\
\hline $\mathrm{CZ}$ & & - & - & $52 \div 54$ & - \\
\hline C content & & $\mathrm{w} \%$ & 85.6 & 86.1 & 74.9 \\
\hline $\mathrm{H}$ content & & $\mathrm{w} \%$ & 12.2 & 13.9 & 25.1 \\
\hline O content & & $\mathrm{w} \%$ & 2.2 & 0 & 0 \\
\hline
\end{tabular}

1) at pressure 1.013 bar; 2) at temperature $0{ }^{\circ} \mathrm{C} ; 3$ ) at $25^{\circ} \mathrm{C} ; 4$ ) at $\lambda=1 ; 5$ ) in air; 6) at pressure 250 bar and temperature $280 \mathrm{~K}$

or less the same engine relevant properties as petrol and thus it is primarily used as an alternative fuel to gasoline (Eichlseder amd Klell, 2010).

In the case of Diesel-engines, the following three solutions can be considered for the use of methane:

a) Conversion of a Diesel-engine over for operation with clean natural gas, which can be achieved by "converting" the Diesel-engine into an Otto-engine (spark ignition engine). This requires significant structural intervention (modification of piston, cylinder head, reduction of compression ratio, installation of ignition / ignition system).

b) Engines converted to pure natural gas at the factory. In this case, serial methane engines are made from serial Diesel-engines.

c) Conversion of diesel engines to dual fuel operation. Ignition of the gas / air mixture is provided by the injection diesel as a "torch". In this case, there are two basic solutions:
- Application of a central gas inlet system when the gas/air mixture is created by means of a throttle/ mixing unit integrated in the suction system;

- In electrically controlled systems, natural gas is introduced separately per cylinder.

The most important elements of the engine's natural gas supply system are as follows:

- High-pressure tanks and their fasteners for the storage of compressed natural gas;

- Piping system for the supply of high pressure gas to the engine and for refueling, and manual, electrical and safety valves;

- Natural gas engine consisting of pressure reducers and pressure regulators;

- Gas supply / mixing units, which can be either so called Venturi-throat or electronic injection valves;

- Catalyst, which can be a simple oxidation one or a 3-way catalyst for engines with electronically controlled injection system (Kiss, 2015). 


\subsection{Properties regarding pollutant-emission}

Hydrogen can be treated as a unique one because it is hydrocarbon-free material, which also means that it allows theoretically a combustion without the formation of $\mathrm{CO}$, $\mathrm{CO}_{2}$, and $\mathrm{CH}$. However, in real engine operation, due to the presence of lubricating oil in the combustion chamber, these pollutants are slightly present in the exhaust gas. When operating with hydrogen, only nitrogen-oxides should be considered as a relevant emission component. In order to enable a jerk-free, smooth switching between the two modes engine power with petrol has to be equivalent to the power running on hydrogen. This is achieved by electronic engine control. Emission values with hydrogen operation are lower during the various driving cycles. Emission values with hydrogen below $2 \%$ against EURO 4 and also against US SULEV (Super Ultra Low Emission Vehicle) limits. Nitrogen-oxides alone is significant, which has a value approximately $30 \%$ compared to the emission limit. Further reduction of nitrogen-oxides to $10 \%$ of the limit is possible with monovalent hydrogen operation (Eichlseder and Klell, 2010). Fig. 6 shows the emission values recorded during the various driving cycles in relation to the limit values.

\section{Comparison and evaluation of different generation fuels based on their presented characteristics}

From point of view of using in internal combustion engines the first-generation biofuels approximate the important properties of fossil fuels, however, some of their properties are disadvantageous. Bioethanol has a significantly higher evaporative heat, which makes cold starting difficult. Due to the higher density and viscosity of biodiesel, it has a detrimental effect on the atomization and hence on the quality of combustion. They have oxygen in their molecular-structure thereby they may improve the combustion and reducing pollutant emissions. The physical-chemical properties of second-generation biofuels are closer to those of fossils. Regarding some properties e.g. density, inflammation tendency can be even better than that of conventional fossil-origin fuels. They are significantly better than those of the first generation.

Because of their different composition, they do not contain or contain only small amounts of certain substances, e.g. oxygen, sulphur, nitrogen, aromatic hydrocarbons, that is because their use significantly reduces the pollutant components of the exhaust gas. For first-generation bio-materials, the individual components are e.g. total $\mathrm{HC}$ decreases, but within this, aldehyde emissions increase.

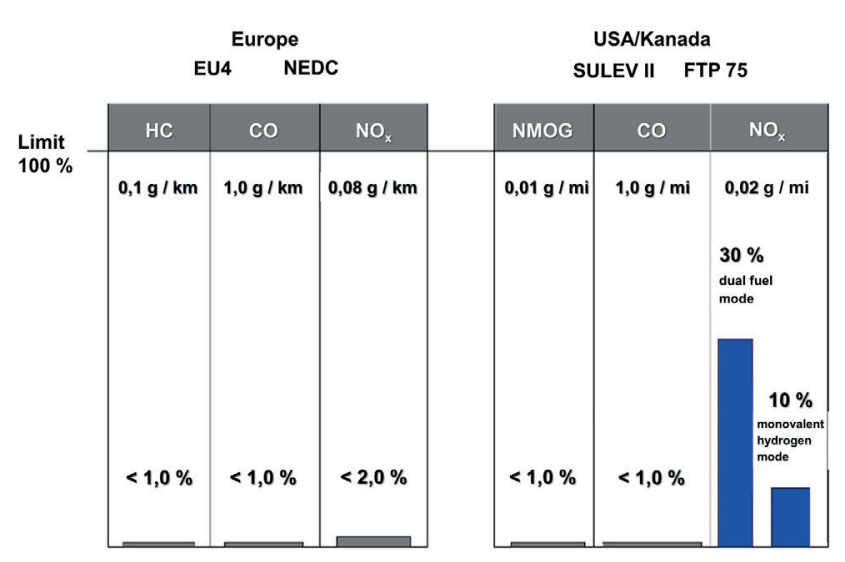

Fig. 6 Emission values measured over different the driving cycles (Eichlseder and Klell, 2010)

Biofuels differ in their energy content from one generation to another. The specific energy content of first-generation fuels is less - but not so much - so close to that of fossils, while the second-generation fuels are nearly the same as conventional ones. Synthetic fuels do not contain or contain some components, e.g. aromatics which reduce the particle emissions during their use. Because of the oxygen bounded in the molecules of first generation fuels, they may burn resulting in less hydrocarbons, particulates and carbon monoxide, while increasing emissions of nitrogen-oxides. Hydrogen and methane are at a significant disadvantage in terms of volume specific energy content. Their disadvantages due to their gaseous state can be reduced by compression, which, in turn, requires complex, expensive systems that the vehicle carries. In case of the internal combustion engines, there can be taken a general statement exactly the amount of pollutants is in correlation with fuel consumption of the engine and the composition of the exhaust gas depending on the composition of the fuel. Hence, hydrogen and methane are the most environmentally friendly fuel.

\section{Summary, outlook}

In this article, the internal combustion engine relevant physical-chemical properties of the first, second and third generation bio-derived fuels and their emission during combustion have been introduced and analyzed.

The first generation bioethanol and biodiesel have different physical-chemical properties than conventional gasoline and diesel have. At present, their widespread slight mixing does not cause disadvantage regarding driving dynamic and fuel consumption. They may be beneficial in terms of emissions because of the oxygen in their molecular structure. 
The properties of synthetic (second generation) biofuels are closer or better in some cases than their fossil counterparts, therefore, their mixing to fossil fuel or even using in a pure form do not have the disadvantages which can appear by fuels of first generation. They also differ in their composition, and do not contain certain components (e.g. sulfur, aromatics) that result in lower emissions due to their use.

Third-generation methane and hydrogen have provided the most significant environmental benefits. They can be used as fuel for internal combustion engines in terms of physical-chemical properties but this requires significant additional infrastructure on the vehicle, which makes it difficult to spread. Although they operate in certain countries e.g. Italy has a significant number of gas vehicles, however, the use of liquid fuels is dominant actually worldwide.

Using of biofuels can be a solution for reduction of $\mathrm{CO}_{2}$ emission if this is possible from point of view of blending rate and specific fuel consumption of an engine. Blending rate to fossil fuels is in a low level nowadays, which means that with the same level in increasing of fuel consumption they are not counted as $\mathrm{CO}_{2}$ reducer any more. This situation seems to be true for all the biofuels which have inherent oxygen which reduces the heating value of the fuel. And this is only an evaluation regarding tank-to-wheel level.

As for air pollution comes from engines running on biofuel biofuels can have advantages regarding certain components like $\mathrm{CO}, \mathrm{HC}$, they decrease generally while using biofuel. Other emission-components for example nitrogen-oxides and particulate mass may increase or changeable in engines running on biofuels compared to conventional fossil derived diesel.

The vision of the authors can be summarized with regards to using biofuels as follows: First-generation fuels are expensive components, they are not supported by automakers for their high blending rate into today's state-ofthe-art engines. The reason for their use in terms of their physical-chemical properties and emissions is not smashing. The use of synthetic fuels in two of the aspects examined is more justified and their cost-effective production also improves their perception. There is currently a learning process in manufacturing technology with low market penetration. Hydrogen and methane are considered third generation when produced on a renewable basis. Gas technology can be a good basis for hydrogen. However, the use of hydrogen as a fuel for internal combustion engines is highly unlikely due to expensive technology that is still immature. Biofuels of 4th generation have been studying from production technology point of view and hardly from utilization point of view.

There is a multidirectional search of way in connection with biofuels. Probably will not be one kind of material that can spread, but the fuel divergence will further expand. The spread of any one will not be significantly influenced by its usability in the engines or the reduction of the environmental load it achieves, but by other, more important, factors already mentioned, such as energy security, long-term preservation of fossil fuels, or fuel diversification.

\section{Acknowledgement}

The research reported in this paper has been supported by the National Research, Development and Innovation Fund (TUDFO/51757/2019-ITM), Thematic Excellence Program.

$\begin{array}{ll}\text { Nomenclature } \\ \text { ICE } & \text { Internal Combustion Engine; } \\ \text { EU } & \text { European Union; } \\ \text { CO } & \text { Carbon-Monoxide; } \\ \text { HC } & \text { Hydrogen-Carbon; } \\ \mathrm{CO}_{2} & \text { Carbon-Dioxide; } \\ \text { MTBE } & \text { Methyl Tert-Butyl Ether; } \\ \text { TAME } & \text { Tert-Amyl Methyl Ether; } \\ \text { ETBE } & \text { Ethyl-Tert-Butyl-Ether; } \\ \text { TAEE } & \text { Tert-Amyl-Ethyl-Ether; } \\ \mathrm{N}_{2} \mathrm{O} & \text { Nitrous-Oxide; } \\ \text { E10 } & \text { Fuel with 10 V/V \% ethanol content; } \\ \text { RME } & \text { Rapeseed Fatty Acid Methyl Ester; } \\ \text { GHG } & \text { Greenhouse Gas; } \\ \text { NO } & \text { Nitrogen-oxides; } \\ \text { B100 } & \text { Fuel with 100 V/V \% biodiesel content; } \\ \text { FTL } & \text { Fischer-Tropsch liquid; } \\ \text { DME } & \text { Dimethyl-ether; } \\ \text { SO } & \text { Sulphur-oxides; } \\ \text { PM } & \text { Particulate Matter; } \\ \text { VOC } & \text { Volatile Organic Compounds; } \\ \text { FAME } & \text { Fatty-Acid-Methyl-Ether; } \\ \text { GTL } & \text { Gas-To-Liquid; } \\ \text { EN } & \text { European Norm; } \\ \text { CEN } & \text { European Committee for Standardisation; } \\ \text { WWFC } & \text { WorldWide Fuel Charter; } \\ \text { PAH } & \text { Polycyclic Aromatic Hydrocarbon; } \\ \text { NEDC } & \text { New European Driving Cycle; } \\ \text { HVO } & \text { Hydrotreated Vegetable Oil; } \\ & \end{array}$

\section{Nomenclature}

ICE Internal Combustion Engine;

EU European Union;

CO Carbon-Monoxide;

$\mathrm{HC}$ Hydrogen-Carbon;

Carbon-Dioxide

Ether

Tert-Amyl Methyl Ether;

Ethyl-Tert-Butyl-Ether

Tert-Amyl-Ethyl-Ether;

$\mathrm{N}_{2} \mathrm{O} \quad$ Nitrous-Oxide

E10 Fuel with $10 \mathrm{~V} / \mathrm{V} \%$ ethanol content

Rapeseed Fatty Acid Methyl Ester;

B100 Fuel with $100 \mathrm{~V} / \mathrm{V} \%$ biodiesel content

FTL Fischer-Tropsch liquid

DME Dimethyl-ether;

$\mathrm{SO}_{\mathrm{x}} \quad$ Sulphur-oxides;

PM Particulate Matter;

FAME Fatty-Acid-Methyl-Ether;

GTL Gas-To-Liquid

European Norm;

European Committee for Standardisation;

WWFC WorldWide Fuel Charter;

NEDC New European Driving Cycle; 


$\begin{array}{ll}\text { BTL } & \text { Biomass-To-Liquid; } \\ \text { ROZ } & \text { Research Octane Number; } \\ \text { MZ } & \text { Engine Octane Number; } \\ \text { CZ } & \text { Cetane Number; } \\ \lambda & \text { air to fuel ratio; } \\ \text { C } & \text { Carbon; } \\ \text { H } & \text { Hydrogen; }\end{array}$

\section{References}

Abdullah, B., Faua'ad Syed Muhammad, S. A., Shokravi, Z., Ismail, S., Kassim, K. A., Mahmood, A. N., Aziz, M. A. (2019) "Fourth generation biofuel: A review on risks and mitigation strategies", Renewable and Sustainable Energy reviews, 107, pp. 37-50. https://doi.org/10.1016/j.rser.2019.02.018

Ahmed, W., Sarkar, B. (2018) "Impact of carbon emissions in a sustainable supply chain management for a second generation biofuel", Journal of Cleaner Production, 186, pp. 807-820. https://doi.org/10.1016/j.jclepro.2018.02.289

Ajanovic, A. (2010) "Die Relevanz alternativer Energieträger der Zukunft im Transportbereich (The relevance of alternative energy sources in the future and on the field of transport)", Vienna University of Technology, Energy Economics Group, Vienna, Austria. (in German)

Alalwan, H. A., Alminshid, A. H., Aljaafari, H. A. S. (2019) "Promising evolution of biofuel generations. Subject review", Renewable Energy Focus, 28, pp. 127-139. https://doi.org/10.1016/j.ref.2018.12.006

Alaswad, A., Dassisti, M., Prescott, T., Olabi, A. G. (2015) "Technologies and developments of third generation biofuel production", Renewable and Sustainable Energy Reviews, 51, pp. 1446-1460. https://doi.org/10.1016/j.rser.2015.07.058

Barabás, I., Todoruț, I. A., Zöldy, M. (2015) "The Potential of BiodieselPetrodiesel-Bioethanol Blends as an Alternative Fuel for Compression Ignition Engines. Energy Science and Technology", Studium Press LL, Houston, TX, USA

Bhatia, S. K., Kim, S. H., Yoon, J. J., Yang, Y. H. (2017) "Current status and strategies for second generation biofuel production using microbial systems", Energy Conversion and Management, 148, pp. 1142-1156.

https://doi.org/10.1016/j.enconman.2017.06.073

Brennan, L., Owende, P. (2010) "Biofuels from microalgae-A review of technologies for production, processing, and extractions of biofuels and co-products", Renewable and Sustainable Energy Reviews, 14(2), pp. 557-577. https://oi.org/10.1016/j.rser.2009.10.009

Capros, P., Mantzos, L., Tasios, N., De Vita, A., Kouvaritakis, N. (2010) "European energy and transport: trends to 2030-update 2009", Office for Official Publication of the European Communities, Brussels, Belgium.

CIVITAS "Creating a biodiesel bus fleet", [online] Available at: https://civitas.eu/measure/creating-biodiesel-bus-fleet [Accessed: 01 March 2019]

$\begin{array}{ll}\text { O } & \text { Oxygen; } \\ \text { LNG } & \text { Liquified Natural Gas; } \\ \text { US SULEV } & \text { United States Super Ultra Low Emission } \\ & \text { Vehicle; } \\ \text { NMOG } & \text { Non-Methane Organic Gas; } \\ \text { km } & \text { kilometre; } \\ \mathrm{mi} & \text { mile; }\end{array}$

Dahman, Y., Syed, K., Begum, S., Roy, P., Mohtasebi, B. (2019) "14 - Biofuels: Their characteristics and analysis", Biomass, Biopolymer-Based Materials, and Bioenergy, pp. 277-325. https://doi.org/10.1016/B978-0-08-102426-3.00014-X

Dechambre, D., Thien, J., Bardow, A. (2017) "When 2nd generation biofuel meets water-The water solubility and phase stability issue", Fuel, 209, pp. 615-623. https://doi.org/10.1016/j.fuel.2017.07.110

Dragone, G., Fernandes, B. D., Vicente, A., Teixeira, J. A. (2010) "Third generation biofuels from microalgae", In: Current research, technology and education topics in applied microbiology and microbial biotechnology, pp. 1355-1366, Badajoz, Spain.

Economics, B. E. "BP Energy Outlook 2018 Edition", [pdf] Available at: https://www.bp.com/content/dam/bp/business-sites/en/global/ corporate/pdfs/energy-economics/energy-outlook/bp-energyoutlook-2018.pdf [Accessed: 01 March 2019]

Eichlseder, H., Klell, M. (2010) "Wasserstoff in der Fahrzeugtechnik: Erzeugung, Speicherung, Anwendung" (Hydrogen in the automotive technology: Production, Storage, Application), SpringerVerlag, Berlin, Germany. (in German)

European Committee For Standardization (2005) "European Standard EN 590 Automotive fuels. Diesel. Requirements and test methods", CEN - European Committee For Standardization, Brussels, Belgium.

European Committee For Standardization (2008) "European Standard EN 14214, Automotive fuels - Fatty acid methyl esters (FAME) for diesel engines - Requirements and test methods", CEN - European Committee For Standardization, Brussels, Belgium.

European Committee For Standardization (2008) "European Standard EN 15376, Automotive fuels - Ethanol as a blending component for petrol. Requirements and test methods", CEN - European Committee For Standardization, Brussels, Belgium.

European Parliament and Council "Directive 2009/28/EC of the European Parliament and of the Council of 23 April 2009 on the promotion of the use of energy from renewable sources and amending and subsequently repealing Directives 2001/77/EC and 2003/30/EC" Strasbourg, France.

Exxon Mobil "2018 Outlook for Energy: A View to 2040", [pdf] Available at: https:/www.ief.org/_resources/files/events/ief-lectureexxonmobils-2018-outlook-for-energy-a-view-to-2040/2018outlook-for-energy.pdf [Accessed: 01 March 2019]

Fischer, G., Schrattenholzer, L. (2001) "Global bioenergy potentials through 2050", Biomass and Bioenergy, 20(3), pp. 151-159. https://doi.org/10.1016/S0961-9534(00)00074-X 
Gruden, D. (2008) "Umweltschutz in der Automobilindustrie "(Environmental protection in the automotive industry), Vieweg+ Teubner-GWV Fachverlage GmbH, Wiesbaden, Germany

Hancsók, J., Krár, M., Baladincz, J., Vuk, T. (2006a) "Dízelgázolajok bioeredetủ komponensei" (Zsírsav-metilészterek), (Bio-origin components of diesel (Fatty acid methyl esters)), Magyar Kémikusok Lapja (Journal of Hungarian Chemists), 61(7), pp. 228-235. (in Hungarian)

Hancsók, J., Magyar, S., Szoboszlai, Z. (2006b) "Motorbenzinek bioeredetű komponensei I. (Bioalkoholok)" (Bio-origin components of gasoline I. (Bioalcohols)), Magyar Kémikusok Lapja (Journal of Hungarian Chemists), 61(5), pp. 153-159. (in Hungarian)

International Energy Agency "World Energy Outlook 2018, Executive summary" [pdf] Available at: https://webstore.iea.org/download/ summary/190?fileName=English-WEO-2018-ES.pdf [Accessed: 01 March 2019]

Kiss, M. D. (2015) "Gázüzemủ belsőégésủ motorok a közúti közlekedésben" (Gas-fueled internal combustion engines for road transport), Diploma thesis, Budapest University of Technology and Economics. (in Hungarian)

Larson, E. D. (2008) "Biofuel production technologies: status, prospects and implications for trade and development", In: United Nations Conference on Trade and Development, Geneva, Italy, pp. 1-31.

Leong, W. H., Lim, J. W., Lam, M. K., Uemura, Y., Ho, Y. C. (2018) "Third generation biofuels: A nutritional perspective in enhancing microbial lipid production", Renewable and Sustainable Energy Reviews, 91, pp. 950-961.

https://doi.org/10.1016/j.rser.2018.04.066

Mączyńska, J., Krzywonos, M., Kupczyk, A., Tucki, K., Sikora, M., Pińkowska, H., Bączyk, A., Wielewska, I. (2019) "Production and use of biofuels for transport in Poland and Brazil-The case of bioethanol", Fuel, 241, pp. 989-996.

https://doi.org/10.1016/j.fuel.2018.12.116

MOL Group "Bioüzemanyagok: A MOL-csoport kiadványa" (Biofuels: Publication of MOL Group), [online] Available at: https://docplayer. hu/5551167-Biouzemanyagok-a-mol-csoport-kiadvanya.html [Accessed: 04 October 2012] (in Hungarian)

Paraffinic Fuels for Europe "Paraffinic Fuels: Environmental benefits" [pdf] Available at: http://www.synthetic-fuels.eu/images/ASFE_ paper_-_Paraffinic_fuel_Emission_ compa rison.pdf [Accessed: 01 March 2019]

Rantanen, L., Linnaila, R., Aakko, P., Harju, T. (2005) "NExBTLBiodiesel fuel of the second generation", SAE Technical Paper Series, pp. 1-19. https://doi.org/10.4271/2005-01-3771

Reijnders, L. (2019) "Is the Production of Biofuels Environmentally Sustainable?", Encyclopedia of Renewable and Sustainable Materials, 3, pp. 545-550. https://doi.org/10.1016/B978-0-12-803581-8.11018-5

RICARDO "Europe's Clean Mobility Outlook: Scenarios for the EU light-duty vehicle fleet, associated energy needs and emissions, 2020-2050", [pdf] Available at: https://www.epure.org/media/1751/ ed51122_epure_cmp_modelling_final-report_issue3-1.pdf [Accessed: 01 March 2019)]

Rimkus, A., Žaglinskis, J., Rapalis, P., Skačkauskas, P. (2015) "Research on the combustion, energy and emission parameters of diesel fuel and a biomass-to-liquid (BTL) fuel blend in a compression-ignition engine", Energy Conversion and Management, 106, pp. 1109-1117.
Saladini, F., Patrizi, N., Pulselli, F. M., Marchettini, N., Bastianoni, S. (2016) "Guidelines for emergy evaluation of first, second and third generation biofuels", Renewable and Sustainable Energy Reviews, 66 , pp. 221-227.

https://doi.org/10.1016/j.rser.2016.07.073

Shell International BV "Shell Energy Scenarios to 2050", [pdf] Available at: https://rjohnwilliams.files.wordpress.com/2016/02/ shell-energy-scenarios2050.pdf [Accessed: 01 March 2019]

Shell "Shell Energy Transition Report", [pdf] Available at: https://www.shell.com/energy-and-innovation/the-energyfuture/shell-energy-transition-report/_jcr_content/par/toptasks. stream/1524757699226/3f2ad7f01e2181c302cdc453c5642c 77acb48ca3/web-shell-energy-transition-report.pdf [Accessed: 01 March 2019]

Then, C., Potthof, C., Hamberger, S. (2010) "Synthetische Biologie und künstliches Leben-eine kritische Analyse" (Synthetic biology and artifical life - a critically analysis), Institut für unabhängige Folgenabschätzung in der Biotechnologie, Münich, Germany (in German)

Torok, A., Zoldy, M. (2010) "Energetic and economical investigation of greenhouse gas emission of Hungarian road transport sector", Pollack Periodica, 5(3), pp. 123-132.

https://doi.org/10.1556/Pollack.5.2010.3.10

Tóth, B. (2011) "Bioüzemanyag elóállítás a fenntarthatóság tükrében" (Production of biofuels in the context of sustainability), presented at Szakmai fórum: Gépjármü-hajtóanyagok, különös tekintettel a bio-komponensekre (Professional forum: Automotive fuels with special regard to bio-components), Budapest, Hungary, Apr. 14, 2011. (in Hungarian)

Vidal Quadras, A. (2010) "The Alliance for Synthetic Fuels in Europe (ASFE): How synthetic fuels can contribute to energy security, air quality and $\mathrm{CO} 2$ reductions", Presentation in the European Parliament, Brussels, Belgium.

Whittaker, C., McManus, M. C., Hammond, G. P. (2011) "Greenhouse gas reporting for biofuels: a comparison between the RED, RTFO and PAS2050 methodologies", Energy Policy, 39(10), pp. 5950-5960. https://doi.org/10.1016/j.enpol.2011.06.054

Zöldy, M. (2018) "Legal Barriers of Utilization of Autonomous Vehicles as Part of Green Mobility", In: Burnete, N., Varga, B. (eds) Proceedings of the 4th International Congress of Automotive and Transport Engineering, pp. 243-248, Springer, Cham, Switzerland. https://doi.org/10.1007/978-3-319-94409-8_29

Zöldy, M. (2009) "Potential future renewable fuel challenges for internal combustion engine", Jármûvek és Mobilgépek, 2, pp. 397-403.

Zöldy, M., Holló, A., Krár, M., Thernesz, A. (2011) "Bio-és biotartalmú motorhajtóanyagok alkalmazástechnikája jó ez nekünk és jó ez a motoroknak?" (Application technology for bio- and bio-containing motor fuels: is it good for us and good for engines?), In: 42. Bus Expert Meeting, Balatonvilágos, Sept. 8-9, Hungary. (in Hungarian)

Zöldy, M., Török, Á. (2015) "Road Transport Liquid Fuel Today and Tomorrow: Literature Overview", Periodica Polytechnica Transportation Engineering, 43(4), pp. 172-176.

https://doi.org/10.3311/PPtr.8095 